Note

\title{
OCCURRENCE AND HOST SPECIFICITY OF INDIGENOUS RHIZOBIA FROM SOILS OF SÃO PAULO STATE, BRAZIL
}

\author{
Maria Luiza Colognesi de Oliveira Lombardi; Milene Moreira²*; Luís Alberto Ambrósio; \\ Elke Jurandy Bran Nogueira Cardoso ${ }^{3}$ \\ ${ }^{1}$ IAC - Centro de Pesquisa e Desenvolvimento de Solos e Recursos Ambientais, C.P. 28 - 13012-970 - Campinas, \\ $S P$ - Brasil. \\ ${ }_{2}^{2}$ APTA - Pólo Médio Paranapanema, C.P. 263 - 19800-970 - Assis, SP - Brasil. \\ ${ }^{3}$ USP/ESALQ - Depto. de Ciência do Solo, C.P. 9 -13418-900 - Piracicaba, SP - Brasil. \\ *Corresponding author <mmoreira@apta.sp.gov.br>
}

\begin{abstract}
The occurrence of rhizobial communities at four sites under natural vegetation and one site under pasture were examined. Isolates of rhizobia originating from crotalaria (C. junceae), common bean (Phaseolus vulgaris) and pigeon pea (Cajanus cajan) were studied in relation to population density, host specificity and the interaction between rhizobial occurrence, climatic conditions and soil properties. $\mathrm{pH}$ values and potential acidity were the soil properties that most affected rhizobial occurrence. Rhizobia from crotalaria and common bean were evaluated at four sites, and from pigeon pea, at five sites. Common bean was the most specific legume, followed by peanuts, crotalaria and pigeon pea.
\end{abstract}

Key words: Rhizobium, Bradyrhizobium, crotalaria, pigeon pea, common bean

\section{OCORRÊNCIADE RIZÓBIOS NATIVOS EM PLANTAS HOSPEDEIRAS DE SOLOS DO ESTADO DE SÃO PAULO, BRASIL}

\begin{abstract}
RESUMO: Foi examinada a ocorrência de comunidades de rizóbios em quatro locais de vegetação natural e um local de pastagem. Isolados de rizóbio originados de crotalária (C. junceae), feijão (Phaseolus vulgaris) e guandu (Cajanus cajan) foram estudados em relação à densidade populacional, planta hospedeira e interação entre ocorrência de rizóbio, condições climáticas e propriedades do solo. Os valores de pH e potencial de acidez foram as propriedades do solo que mais contribuíram para a ocorrência de rizóbio. A ocorrência de rizóbio em crotalária e feijão foi estudada em quatro locais, e em guandu em cinco locais. O feijão foi mais específico, seguido por crotalária e guandu.

Palavras-chave: Rhizobium, Bradyrhizobium, crotalária, guandu e feijão
\end{abstract}

\section{INTRODUCTION}

Biological nitrogen fixation is a vital component of agricultural sustainability, and the understanding of rhizobial diversity in different ecosystems is therefore fundamental. It is necessary to consider the complexity of the interactions among rhizobia and the soil characteristics that influence the occurrence and diversity of these microorganisms in natural ecosystems. Also, the discovery of new genetic materials that can be used in biotechnological applications is essential for sustainable agriculture.

Cultivated areas containing Neonotonia wightii (Lopes et al., 1972), peanut (Giardini et al., 1985; Lombardi et al., 1992) or green manure legumes (Chada \& De Polli, 1988; Rodrigues et al., 1994, Zilli et al., 2004) were capable of maintaining rhizobial communities that were highly infective for their host plants and well adapted to soil conditions. Several studies in- dicated that the rhizobial communities can be affected by the properties of the soil and by the host plants (Palmer \& Young, 2000, Zhang et al., 2001; Laguerre et al., 2003), as well as by soil tillage (Cattelan \& Vidor, 1990; Castro et al., 1993, Carvalho et al., 2004), and crop history (Venkatesvarlu et al., 1997).

The natural vegetation in the State of São Paulo is composed of forest, savanna (cerrado) and "cerradão", but little is known about communities of rhizobia in these areas. Although the presence of the leguminous host is one of the determinants of the size of the rhizobial population, other factors, such as environmental stresses, soil acidity and the presence of toxic elements in the soil, may play an important role in the establishment of rhizobial communities (Kahindy et al., 1997). Brazilian soils are in general acidic and can present high exchangeable aluminum concentrations, a factor that can limit rhizobial survival. 
A survey of the presence of rhizobial strains was conducted at four sites under natural vegetation and one site under pasture in the State of São Paulo, Brazil. Rhizobia and bradyrhizobia were isolated from soil using Phaseolus vulgaris, Crotalaria juncea and Cajanus cajan as trap hosts. The population density of rhizobia nodulating each host plant was evaluated. The objective of this study was to examine the occurrence and diversity of the rhizobial communities at the sites and to determine whether the presence of the rhizobial strains is dependent on soil chemical properties.

\section{MATERIALAND METHODS}

\section{Soil samples}

Soil samples were collected at five sites with different plant covers: (i) cerradão (Morro Agudo $20^{\circ} 43^{\prime} \mathrm{S}$ and $48^{\circ} 55^{\prime} \mathrm{W}$ ); (ii) savanna (cerrado) (Campinas - 22 $2^{\circ} 53^{\prime} \mathrm{S}$ and $47^{\circ} 04^{\prime} \mathrm{W}$ ); (iii) Paspalum notatum pasture (Anhembi - 24. $48^{\prime} \mathrm{S}$ and $48^{\circ} 07 \mathrm{~W}$ ), and (iv) forest (Pariquera-Açu - 24. ${ }^{\circ} 43^{\prime}$ S and 47 ${ }^{\circ} 52^{\prime}$ $\mathrm{W}$, and Pindorama - $21^{\circ} 13^{\prime} \mathrm{S}$ and $48^{\circ} 55^{\prime} \mathrm{W}$ ). Some native legumes mixed under the native vegetation were observed at Anhembi, Campinas and Morro Agudo, while no leguminous plants were found at the two other sites. The soil types corresponding to these areas are: Kandiudult, under pasture in Anhembi, Hapludox under savanna in Campinas (Oliveira et al., 1976), Eutrudox under forest, in Pariquera-Açu (Sakai \& Lepsch, 1984), and Kanhapludult in Pindorama (Lepsch \& Valadares, 1976). The temperature and precipitation regimes of the different regions were quite variable (Figure 1).
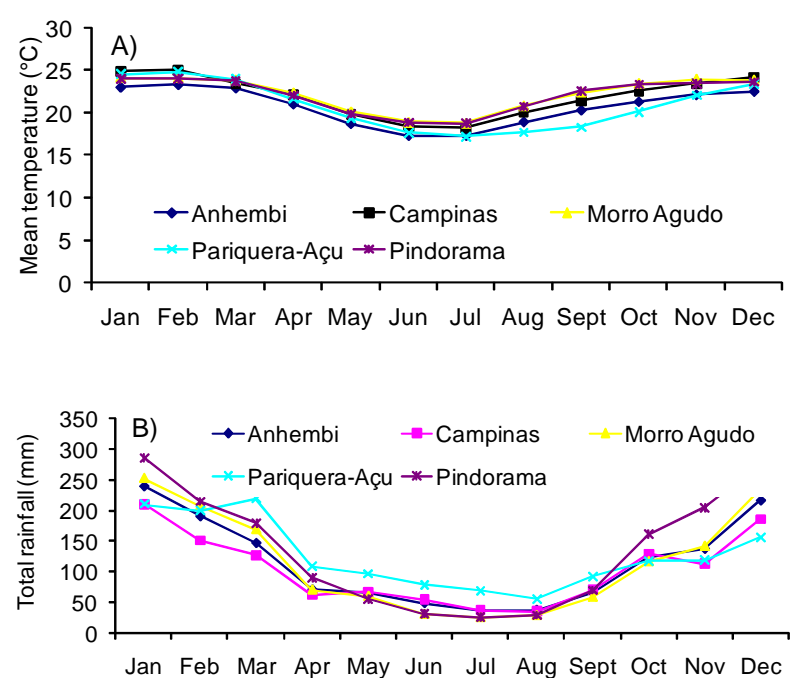

Figure 1 - Monthly distribution of (a) mean temperature and (b) total rainfall at sites from which soils were sampled. Means were for 1961-1990.
Soil samples were collected at the top layer (0-20 cm depth) and consisted of 20 sub-samples taken at a distance of at least $15 \mathrm{~m}$ between the sampling points. The sub-samples were mixed and submitted to chemical analysis (Table 2).

\section{Rhizobial counts in soil}

A greenhouse experiment was carried out in plastic pots $\left(300 \mathrm{~cm}^{3}\right)$ filled with sterilized sand. Seeds of crotalaria were sterilized with concentrated sulphuric acid for three minutes and washed with sterilized water. Seeds of common bean and pigeon pea were disinfected with a $5 \%$ solution of sodium hypochlorite for five minutes and washed with sterilized water. Three seeds of each legume were planted per pot and, after 5 days, seedlings were thinned to one per pot. A fourfold soil dilution series $\left(4^{-4}\right.$ to $\left.4^{-7}\right)$ with three replicates for each soil type and four replicates for each dilution was used to determine the Rhizobium most probable number (Somasegaran \& Hoben, 1985). Each pot received $1 \mathrm{~mL}$ of each soil dilution. Pots were distributed in a completely randomized design in a greenhouse, and plants were supplied weekly with minus $\mathrm{N}$ nutrient solution (Norris, 1965). The pots were irrigated with sterilized water, whenever necessary. Plants were harvested 40 days after planting. Non-inoculated control plants were sown in sterilized sand, to verify the aseptic conditions of the experiment, in addition to the plants grown in this experiment.

\section{Nodule formation and rhizobia isolation}

Crotalaria, common bean and pigeon pea were cultivated in plastic pots $\left(500 \mathrm{~cm}^{3}\right)$ with washed and sterilized sand plus soil, in a proportion of two parts of sand $\left(300 \mathrm{~cm}^{3}\right)$ to one part of soil $\left(150 \mathrm{~cm}^{3}\right)$. Controls were set up in pots that contained only sterilized sand. Seeds of each legume were prepared as in the first experiment. Six seeds for each host plant were planted per pot and, after five days, seedlings were thinned to two per pot. The pots were distributed in a greenhouse, in a completely randomized design. Plants were harvested 40 days after planting.

Nodules of the five replicates of each legume and of each soil were removed, mixed, counted and six nodules were chosen at random for isolation of rhizobia, according to Vincent (1970).

\section{Statistical analysis}

Analyses of variance were conducted to test the effects of the treatments corresponding to different sites and host plants, on $\log _{10}$ transformed data for rhizobial number $\left[\log _{10}(\mathrm{CFU}+1)\right]$, with the $\mathrm{F}$ test for treatments at the $5 \%$ level of significance. For multiple comparisons of means of the five sites (Anhembi, Campinas, Morro Agudo, Pariquera-Açu, and 
Pindorama) and three host plants (Crotalaria, Common bean, and Pigeon pea) the Tukey test at the 5\% level of significance was used.

To identify a useful subset of predictors of rhizobial number (CFU) in soil, a stepwise regression was used which removes or adds variables to the regression model (Yamane, 1973). These variables are removed or added if their $p$ - values are greater than the alpha value, alpha here considered as 0.25 for the F-to-enter and F-to-remove test. The high value of 0.25 for alpha that increases the rejection zone of the null hypothesis (H0) is due to the exploratory character of this investigation. Therefore, all potential predictor variables (even those with low values) are included in this model to explain the variations of the dependent variable (Conagin et al., 2006). The $\log _{10}$ (CFU+1) values were considered as the predicted variable and the predictor variables were the soil properties: $\mathrm{pH}, \mathrm{Al}^{+3}$, organic matter, $\mathrm{H}+\mathrm{Al}$, sum of bases, bases saturation and phosphorus level. The winter temperatures and precipitation means for May, June, July and August were also considered as predictor variables.

\section{RESULTS}

All soil samples contained either slow growing or fast growing Rhizobium or Bradyrhizobium species, generally in low numbers, that varied from $12.7 \mathrm{cfu}$ $\mathrm{g}^{-1}$ soil for pigeon pea in Pariquera-Açu to $783 \mathrm{cfu} \mathrm{g}^{-1}$ soil for bean plants in Morro Agudo (Table 3). In Pariquera-Açu, with the most acidic soil, the lowest rhizobial numbers were found, while Morro Agudo presented the highest total rhizobial numbers. Table 4 shows the descriptive statistics for the observations of the sites. Campinas was not considered because the high rhizobial numbers (mean $=65.7$ ) in combination with the low base saturation value (mean $=3.0$ ) in this location differed totally from those found at the other sites. However, no special attempt was made to really classify the bacteria at the species or even at the genus level.

The model fitted by stepwise regression analysis was:

$\log _{10}(\mathrm{cfu}+1)=\mathrm{a}+\mathrm{b}_{1} \mathrm{pH}+\mathrm{b}_{2} \mathrm{H}+\mathrm{Al}$

The adjusted determination coefficient $\left(\mathrm{R}^{2}{ }_{\text {adj }}\right)$ shows that $64.16 \%$ of the variability of $\log _{10}(\mathrm{cfu}+1)$ accounted for the model. Results referring to legume nodulation in each soil are presented in Table 5, and the same tendency was observed: common bean cultivated in Morro Agudo presented the highest nodule number, and pigeon pea cultivated in Pariquera-Açu the lowest. The $\mathrm{pH}$ and $(\mathrm{H}+\mathrm{Al})$ were the soil properties that contributed most to the rhizobial occurrence in soils, with a significance level of $5 \%$. Common bean rhizobia were more specific than those of other legumes (Table 6). Peanut and crotalaria did not nodulate with isolates originated from common bean.

The F test of the ANOVA showed that the main effects of sites and host plants and their interactions upon the variable log $(\mathrm{cfu}+1)$ were highly significant $(p<$ $0.0001)$. Thus, we compared the means of $\log (\mathrm{cfu}+1)$ for each host plant at each site, using the Tukey test $(p<0.05)$ (Table 7).

\section{DISCUSSION}

Temperature and rainfall distribution (Figure 1) showed a certain variation form site to site, but normally followed the expected pattern of a warn and rainy summer, followed by a colder and drier winter with low temperatures and a very low soil pH. Morro Agudo under savanna vegetation and Anhembi had the highest $\mathrm{pH}$ values and there, all three legumes produced nodules. However, in Campinas, with a much lower $\mathrm{pH}$ value and a medium clayey texture soil, there was also generalized nodulation, while in Pindorama, with a much higher $\mathrm{pH}$ value and a very sandy texture, crotalaria failed to nodulate. Finally, in the forest soil from Pariquera-Açu, highly acidic and slightly clayey, most legumes did not nodulate. Only pigeon pea presented some nodules.

For the increase of each $\mathrm{pH}$ unit, there was an increase of $36.6 \mathrm{cfu}$ (antilog =1.5) and for an increase of each $\mathrm{H}+\mathrm{Al}$ unit there was an increase of $1.02 \mathrm{cfu}$ (antilog 0.0076) (Table 1). pH and $\mathrm{H}+\mathrm{Al}$ are soil properties that affect rhizobial growth and can influence the availability of some important nutrients for rhizobia, like phosphorus and calcium. All soils contained indigenous rhizobia capable of inducing nodulation in at least one or more of the host legumes, which agrees with Bala et al. (2003). Numbers as low as $6 \times \mathrm{cfu} \mathrm{g}^{-1}$ soil in four Hawaiian soils cultivated with six legume species were found by Singleton \& Tavares (1986). Woomer et al. (1988) examined fourteen sites with four soils and five legumes and found 1.1 to $4.8 \log _{10}$ cells $\mathrm{g}^{-1}$ soil.

In two sandy soils classified as Kandiudult (pasture and forest) all plants had fewer nodules compared with legumes cultivated in soils with high clay contents such as Hapludox under savanna and Eutrudox

Table 1 - Values of the terms used in the regression analysis.

\begin{tabular}{lccl}
\hline Statistics & Constant Term (a) & $\mathrm{pH}$ & $\mathrm{H}+\mathrm{Al}$ \\
\hline Coefficients & -2.592 & 1.50 & 0.0076 \\
t-value & & 5.56 & 2.67 \\
p-value & & 0.00 & 0.012 \\
\hline
\end{tabular}


Table 2 - Chemical properties of soil samples.

\begin{tabular}{lccccrrrrrr}
\hline Site & $\mathrm{pH} \mathrm{CaCl}_{2}$ & $\mathrm{OM}$ & $\mathrm{P}$ & $\mathrm{K}$ & $\mathrm{Ca}$ & $\mathrm{Mg}$ & $\mathrm{H}+\mathrm{Al}$ & $\mathrm{SB}^{(1)}$ & $\mathrm{Al}$ & $\mathrm{V} \%(2)$ \\
\hline Anhembi & & $\mathrm{g} \mathrm{kg}^{-1}$ & $\mathrm{mg} \mathrm{kg}^{-1}$ & $-\ldots-1$ & & & & \\
Campinas & 5.0 & 1.6 & 5 & 4.3 & 12 & 5 & 25 & 21.3 & 0.20 & 46 \\
Morro Agudo & 3.9 & 3.3 & 2 & 0.9 & 1 & 1 & 99 & 2.9 & 1.40 & 3 \\
Pariquera-Açu & 3.4 & 6.0 & 75 & 6.6 & 68 & 28 & 43 & 102.6 & 0.25 & 70 \\
Pindorama & 4.6 & 2.7 & 8 & 3.5 & 19 & 8 & 32 & 30.5 & 0.01 & 48 \\
\hline
\end{tabular}

${ }^{1} \mathrm{SB}=$ sum of bases; ${ }^{2} \mathrm{~V}=$ base saturation

Table 3 - Rhizobia means as $\log _{10}(\mathrm{cfu}+1)$, found in roots of three legumes planted in soils sampled at sites from the State of São Paulo, Brazil.

\begin{tabular}{lcccccc}
\hline Site & Original vegetation & Natural legumes & Crotalaria & Common bean & Pigeon pea & Total \\
\hline Anhembi & Pasture & 1.45 & 1.45 & 1.76 & 1.41 & 2.05 \\
Campinas & Savanna & 1.76 & 1.76 & 2.01 & 1.57 & 2.29 \\
Morro Agudo & Cerradão & 2.27 & 2.27 & 2.89 & 1.60 & 3.00 \\
Pariquera-Açu & Forest & - & - & - & 1.10 & 1.10 \\
Pindorama & Forest & - & - & 1.31 & 1.56 & 1.75 \\
\hline
\end{tabular}

Table 4 - Descriptive statistical data of four sites.

\begin{tabular}{lcccr}
\hline Parameter & Mean* & Standard error & Minimum & Maximum \\
\hline CFU** & 99.24 & 227.08 & 0.00 & 1100.00 \\
Aluminum & 0.72 & 0.99 & 0.01 & 2.40 \\
pH & 4.58 & 0.80 & 3.30 & 5.40 \\
Organic matter & 3.68 & 1.70 & 1.60 & 6.00 \\
Sum of bases & 40.80 & 37.02 & 8.80 & 102.60 \\
Base saturation & 42 & 24.21 & 4 & 70 \\
Phosphorus & 25 & 29.39 & 5 & 75 \\
H + Al & 76.25 & 75.67 & 25.00 & 205.00 \\
Temperature & 18.89 & 0.95 & 17.97 & 20.10 \\
Precipitation & 48.05 & 16.5 & 34.75 & 74.95 \\
\hline
\end{tabular}

*Means of four sites. Samples from Campinas were not considered (outlier data). CFU** = colony forming units.

Table 5 - Number of nodules per plant when crotalaria, common bean, and pigeon pea were inoculated with Rhizobium isolates from different plants.

\begin{tabular}{lcccrr}
\hline Site & Plant cover & Crotalaria & Common bean & Pigeon pea & Total \\
\hline Anhembi & Pasture & 5.00 & 16.9 & 3.7 & 25.8 \\
Campinas & Savanna & 23.00 & 31.0 & 3.0 & 57.0 \\
Morro Agudo & Cerradão & 31.00 & 87.7 & 18.2 & 137.8 \\
Pariquera-Açu & Forest & n.d.* & n.d.* & 8.0 & 8.0 \\
Pindorama & Forest & n.d.* & 3.2 & 4.9 & 8.1 \\
\hline
\end{tabular}

*n.d. $=$ not detected

under “cerradão". In the clayey Hapludox from Pariquera-Açu, the acidity seems to have affected the rhizobia more than soil texture. Few studies have shown the influence of soil texture on rhizobial communities, but Danso \& Owiredu (1988) observed fewer Vigna unguiculata rhizobia in a sandy or acidic soil compared to a very clayey soil. Similar results were attained by Rupela et al. (1982), who studied rhizobial communities capable of nodulating Cicer arietinum.

The presence of a particular Rhizobium or Bradyrhizobium was correlated with the occurrence 
Table 6 - Host specificity of rhizobia isolates from crotalaria, common bean and pigeon pea: number and percent of nodules from one legume that nodulates the other legumes.

\begin{tabular}{lccccccc}
\hline Original legume & Total isolate & \multicolumn{2}{c}{ Crotalaria } & \multicolumn{2}{c}{ Common bean } & \multicolumn{2}{c}{ Pigeon pea } \\
\hline Crotalaria & no. & no. & $\%$ & no. & $\%$ & no. & $\%$ \\
Common bean & 18 & 18 & 100 & 0 & 0 & 11 & 61 \\
Pigeon pea & 24 & 0 & 0 & 24 & 100 & 0 & 0 \\
\hline
\end{tabular}

Table 7 - Means as $\log (\mathrm{cfu}+1)$ for the different plants at each site.

\begin{tabular}{lccccc}
\hline Host Plant & Anhembi & Campinas & Morro Agudo & Pariquera-Açu & Pindorama \\
\hline Crotalaria & $1.46 \mathrm{ab}$ & $1.76 \mathrm{ab}$ & $2.25 \mathrm{~b}$ & $0.00 \mathrm{~b}$ & $0.00 \mathrm{~b}$ \\
Common bean & $1.76 \mathrm{a}$ & $2.00 \mathrm{a}$ & $2.87 \mathrm{a}$ & $0.00 \mathrm{~b}$ & $1.32 \mathrm{a}$ \\
Pigeon pea & $1.41 \mathrm{~b}$ & $1.56 \mathrm{~b}$ & $1.61 \mathrm{c}$ & $1.05 \mathrm{a}$ & $1.56 \mathrm{a}$ \\
\hline
\end{tabular}

*Values in the columns followed by different letters indicate differences, among the means (Tukey, $p<0.05$ ).

of its appropriate host legume in soils from Hawaii (Woomer et al., 1988). In our study, the highest rhizobial number was observed in common bean in four of five sites examined, and pigeon pea consistently had the fewest nodules (Tables 5). However, pigeon pea was nodulated in all soils. Therefore, these rhizobia were widely distributed, although the populations of pigeon pea rhizobia were not high in any of these soils. Crotalaria did not nodulate in two soils and the lack of nodules in the soil from Pindorama had not been expected because this legume is commonly nodulated in tropical soils (Tables 5 and 6).

All sampling sites, except the Kandiudult under pasture in Anhembi, were under native vegetation: forest, savanna or "cerradão". At all these sites, indigenous legumes were found. In an area close to Campinas, only few alterations in the native floristic composition were found, and Leguminosae prevailed over other plant families and occurred as native herbaceous and woody components (Matthes et al., 1988). This fact may have contributed to the occurrence of rhizobia in all areas where the soils were sampled. The Kandiudult from Anhembi has been cultivated with Paspalum notatum for ten years, and previously had been cultivated with corn. No legumes were observed in this area, but this site was next to areas with native forest which contained shrubs, herbaceous and woody legumes. The legumes used in this study became nodulated by the native communities of rhizobia that were present, and, if we consider the presence of wild legumes in all soils, this nodulation had been expected.

Only bean did not nodulate with the rhizobia from crotalaria and pigeon pea (Table 6). Most isolates from crotalaria (83\%) nodulated peanut and 61\% formed nodules in pigeon pea. Pigeon pea is known to be a highly promiscuous legume and is capable of nodulating with slow and fast growing rhizobia (Bromfield \& Kuma Rao, 1983; Anand \& Droga, 1991). Pigeon pea isolates could be either slow or fast growing. This may explain the poor nodulation demonstrated when peanut was inoculated with isolates from pigeon pea, since peanut is nodulated preferentially by slow-growing rhizobia. Crotalaria did not nodulate with all the isolates from common bean because this legume nodulates only with slow-growing rhizobia and common bean is nodulated only by fastgrowing rhizobia. Also, the fast-growing isolates from pigeon pea were not capable of nodulating crotalaria, probably for the same reason (Table 7). To know the number of indigenous rhizobia in soils is important when soils are to be utilized for agricultural practices. The response to inoculation was affected by the soil population when the number of counted rhizobia was at or above 20 cells $\mathrm{g}^{-1}$ soil (Singleton \& Tavares, 1986).

A better knowledge of these communities can perhaps answer questions about the potential efficacy of legume inoculation in soils of the São Paulo State. Inoculation has not always produced consistent results, especially in areas recently brought into agricultural productivity. In this study the nitrogen fixation efficiency of the isolates was not evaluated, although it is necessary to obtain information about it and also, to obtain new strains for studies.

\section{ACKNOWLEDGEMENTS}

The authors thank Dr. Dilmar Baretta for critical review of the text and Dr. Ricardo M. Coelho for soil classification. Thanks also go to Rosana Gierts for technical assistance. E.J.B.N.C. thanks CNPq for a research fellowship. 


\section{REFERENCES}

ANAND, R.C.; DROGA, R.C. Physiological and biochemical characteristics of fast and slow-growing Rhizobium sp. of pigeon pea (Cajanus cajan). The Journal of Applied Bacteriology, v.70, p.197-201, 1991.

BALA, A.; MURPHY, P.; GILLER, K.E. Distribution and diversity of rhizobia nodulating agroforestry legumes in soils from three continents in the tropics. Molecular Ecology, v.12, p.917930, 2003.

BROMFIELD, E.S.P.; KUMAR RAO, J.V.D.K. Studies on fast and slow-growing Rhizobium spp. nodulating Cajanus cajan and Cicer arietinum. Annual Applied Biology, v.102, p.485-493, 1983.

CARVALHO, M.A.C.; ATHAYDE, M.L.F.; SORATTO, R.P.; ALVES, M.C.;ARF, O. Soja em sucessão a adubos verdes no sistema de plantio direto e convencional em solo de Cerrado. Pesquisa Agropecuária Brasileira v.39, p.1141-1148, 2004.

CASTRO, O.M.; PRADO, H.; SEVERO, A.C.R.; CARDOSO, E.J.B.N. Avaliação da atividade de microrganismos do solo em diferentes sistemas de manejo da soja. Scientia Agricola, v.50, p.212-219, 1993.

CATTELAN, A.J.; VIDOR, C. Sistemas de culturas e a população microbiana do solo. Revista Brasileira de Ciência do Solo, v.14, p.125-132, 1990.

CHADA, S.S.; DE-POLLI, H. Nodulação de leguminosas tropicais promissoras para a adubação verde em solo deficiente em fósforo. Pesquisa Agropecuária Brasileira, v.23, p.1197-1202, 1988.

CONAGIN, A.; NAGAI, V.; AMBRÓSIO, L.A. Princípios de técnica exsperimental e análise estatística de experimentos. Campinas: Instituto Agronômico, 2006. cap. VI. E-book.

DANSO, S.K.A.; OWIREDU, J.D. Competitiveness of introduced and indigenous cowpea Bradyrhizobium strains for nodule formation on cowpeas (Vigna unguiculata (L.) Walp) in three soils. Soil Biology Biochemistry, v.20, p.305-310, 1988.

GIARDINI, A.R.; LOPES, E.S.; SAVY FILHO, A; NEPTUNE, A.M.L. Inoculação com Rhizobium e aplicação de nitrogênio em amendoim. Bragantia, v.44, p.27-39, 1985.

KAHINDY, J.H.P.; WOOMER, P., GEORGE, T.; MOREIRA, F.M.S.; KARANJA, N.K.; GILLER, K.E. Agricultural intensification, soil biodiversity and ecosystem functioning in the tropics: the role of nitrogen-fixing bacteria. Applied Soil Ecology, v.6, p.55-76, 1997.

LAGUERRE, G., LOUVRIER, P., ALLARD, M.R., AMARGER, N. Compatibility of rhizobial genotypes within natural populations of Rhizobium leguminosarum biovar viciae for nodulation of host legumes. Applied and Environmental Microbiology v.69, p.2276-2283, 2003.

LEPSCH, I.F.; VALADARES, J.M.A.S. Levantamento pedológico detalhado da Estação Experimental de Pindorama (SP). Bragantia, v.35, p.13-40, 1976.

LOMBARDI, M.L.C.O.; LOPES, E.S.; FREITAS, S.S.; NOVO, M.C.S.S.; LASCA, D.H.C.; STIVARI, A.; CERÁCULO, L.C. 1992 Resposta do amendoim à inoculação de estirpes de Bradyrhizobium spp. em duas regiões paulistas. Revista Brasileira de Ciência do Solo, v.16, p.177-181, 1992.

LOPES, E.S.; LOVANDI, L.A.C.; GARGANTINI, H.; IGUE, T. Número mais provável e eficiência de Rhizobium autóctone para soja perene e siratro em quatro grandes grupos de solos do Estado de São Paulo. Bragantia, v.31, p.236-247, 1972.
MATTHES, L.A.F.; LEITÃO FO, H.F.; MARTINS, F.R.M. Bosque dos Jequitibás (Campinas, SP): composição florística e estrutura fitossociológica do estrato arbóreo. In: Congresso da Sociedade de Botânica de São Paulo, 5., São Paulo, 2988. Anais. São Paulo: SBSP, 1988. p.55-76.

NORRIS, D.O. Acid production by Rhizobium, a unifying concept. Plant and Soil, v.22, p.143-166, 1965.

OLIVEIRA, J.B.; MENK, J.R.; ROTTA, C.L. Levantamento pedológico semi- detalhado dos solos do Estado de São Paulo: quadrícula de Campinas. Rio de Janeiro: IBGE, 169p. 1976.

PALMER, K.M., YOUNG, J.P.W. Higher diversity of Rhizobium leguminosarum biovar viciae populations in arable soils than in grass soils. Applied and Environmental Microbiology, v.66, p.2445-2450, 2000.

RODRIGUES, E.F.G.; DE-POLLI, E.; EIRA, P.A. Inoculação, calagem e adubação para mucuna preta e feijão de porco num solo podzólico vermelho-amarelo. Pesquisa Agropecuária Brasileira, v.295, p.807-814, 1994.

RUPELA, O.P.; TOOMSAM, B.; MITTAL, S.; DART, P.J.; THOMPSON, J.A. Chickpea Rhizobium population: survey of influence of season, soil depth and cropping pattern. Soil Biology Biochemistry, v.19, p.247-252, 1982.

SAKAI, E.; LEPSCH, I.F. Levantamento pedológico detalhado da Estação Experimental de Pariquera-Açu. Campinas: Instituto Agronômico, 1984. 56p. (Boletim Técnico)..

SINGLETON, P.W.; TAVARES, J.W. Inoculation response of legumes in relation to the number and effectiveness of indigenous Rhizobium population. Applied and Environmental Microbiology, v.51, p.1013-1018, 1986.

SOMASEGARAN, P.; HOBEN, H.J. Methods. In: LegumeRhizobium technology. University of Hawaii, Niftal project and Mircen, 1985. 367p.

VENKATESVARLU, B.; HARI, K.; KATYAL, J.C. Influence of soil and crop factors on the native rhizobial populations in soil under dryland farming. Applied Soil Ecology, v.7, p.1-10, 1997.

VINCENT, J.M. A manual for the practical study of the root nodule bacteria. Oxford: Blackwell Scientific, 1970. 159p. (IBP Handbook, 15).

WOOMER, P.; SINGLETON, P.W.; BOHLOOL, B.B. Ecological indicators of native Rhizobia in tropical soils. Applied and Environmental Microbiology, v.54, p.1112-1116, 1988.

YAMANE, T. Statistics: an introductory analysis. 3 ed. New York, Harper, 1973, p.994-998.

ZHANG, X., KOSIER, B., PRIEFER, U.B. Genetic diversity of indigenous Rhizobium leguminosarum v. viciae isolates nodulating two different host plants during soil restoration with alfalfa. Molecular Ecology, v.10, p.2297-2305, 2001.

ZILLI, J.E.; VALISHESKI, R.R.; FREIRE FILHO, F.R.; NEVES, M.C.P.; RUMJANEK, N.G. Assessment of cowpea rhizobium diversity in Cerrado areas of northeastern Brazil. Brazilian Journal of Microbiology, v.35, p.281-287, 2004.

Received December 17, 2007

Accepted February 16, 2009 